ReVIeW

\title{
Sexual dimorphism and thyroid dysfunction: a matter of oxidative stress?
}

\author{
Rodrigo S Fortunato', Andrea C F Ferreira ${ }^{2}$, Fabio Hecht ${ }^{1,2}$, Corinne Dupuy ${ }^{3}$ \\ and Denise P Carvalho ${ }^{2}$
}

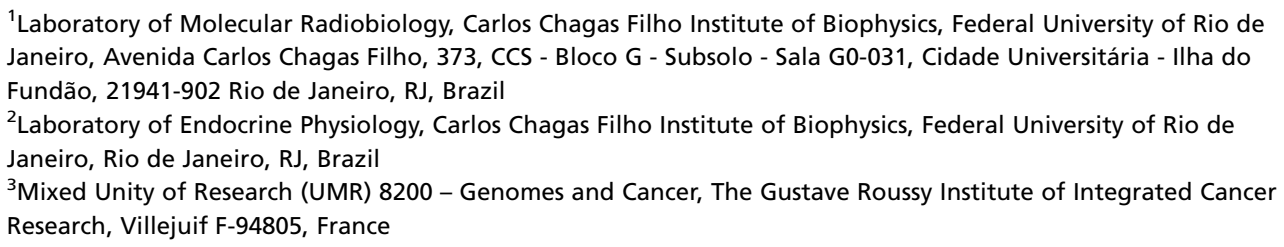

Correspondence should be addressed to R S Fortunato

Email

rodrigof@biof.ufrj.br

\begin{abstract}
Thyroid diseases, such as autoimmune disease and benign and malignant nodules, are more prevalent in women than in men, but the mechanisms involved in this sex difference is still poorly defined. $\mathrm{H}_{2} \mathrm{O}_{2}$ is produced at high levels in the thyroid gland and regulates parameters such as cell proliferation, migration, survival, and death; an imbalance in the cellular oxidant-antioxidant system in the thyroid may contribute to the greater incidence of thyroid disease among women. Recently, we demonstrated the existence of a sexual dimorphism in the thyrocyte redox balance, characterized by higher $\mathrm{H}_{2} \mathrm{O}_{2}$ production, due to higher NOX4 and Poldip2 expression, and weakened enzymatic antioxidant defense in the thyroid of adult female rats compared with male rats. In addition, $17 \beta$-estradiol administration increased NOX4 mRNA expression and $\mathrm{H}_{2} \mathrm{O}_{2}$ production in thyroid PCCL3 cells. In this review, we discuss the possible involvement of oxidative stress in estrogenrelated thyroid pathophysiology. Our current hypothesis suggests that a redox imbalance elicited by estrogen could be involved in the sex differences found in the prevalence of thyroid dysfunctions.
\end{abstract}

\author{
Key Words \\ - estrogen \\ - thyroid \\ - reactive oxygen species \\ - NADPH oxidases
}

\section{Introduction}

Thyroid diseases are more prevalent in women than in men. In the general population, the Framingham survey indicated that the prevalence of diffuse or nodular goiter is $6.4 \%$ in women and $1.5 \%$ in men (Vander et al. 1968), and the Wickham study reported a female-to-male thyroid disease prevalence ratio of 6.6:1 (Tunbridge et al. 1977). Additionally, the incidence of spontaneous hypothyroidism is higher in women than in men, with a mean incidence in women of 3.5/1000 survivors per year (2.8-4.5) and in men of $0.6 / 1000$ survivors per year (0.3-1.2) (Vanderpump et al. 1995). Moreover, the detection of thyroid autoantibodies is almost five times more common in women than in men (Hollowell et al. 2002). The mean incidence of Hashimoto's disease among women is $\sim 3.5$ cases/1000 people per year, whereas in men the incidence is 0.8 cases/1000 people per year (Brent \& Davies 2011). The prevalence of hyperthyroidism in women is $\sim 1 \%$, and in men, it is approximately one-tenth of that,

Published by Bioscientifica Ltd. 
according to The National Health and Nutrition Examination Survey data from the USA, and it seems to be more prevalent after puberty (Mandel et al. 2011). Therefore, one can hypothesize that either sexual chromosomes and/or gonadal hormones are able to profoundly affect thyroid physiology and pathophysiology. In the present review, we focus on the known effects of estrogen on the thyroid gland and the possible involvement of reactive oxygen species (ROS) in the marked sexual dimorphism found in thyroid diseases, with women being most affected.

\section{Review}

\section{Estrogen receptors in the thyroid gland}

For decades, the thyroid gland has been known to be a target of estrogen (Molteni et al. 1979, Hampl et al. 1985, Schaefer et al. 1986). Nuclear estrogen receptors ER $\alpha$ and ER $\beta$ are ligand-regulated transcription factors and are classified as class I members of the superfamily of steroid/thyroid hormone nuclear receptors (Green et al. 1986, Mangelsdorf et al. 1995, Couse \& Korach 1999, Cui et al. 2013). As such, binding of estrogen to ERs leads to the translocation of the hormone-receptor complex into the nucleus and interaction with DNA, specifically with the estrogen-responsive elements present in the promoter regions of target genes (Marino et al. 2006). In addition to nuclear ERs, which mediate the majority of the known effects of estrogens, some rapid effects of estrogens are transduced by ERs present at the cell membrane that activate intracellular signaling cascades (Pedram et al. 2006, Levin 2009, Cui et al. 2013). Membrane-localized $\mathrm{ER} \alpha$ and ER $\beta$ activate $\mathrm{G} \alpha \mathrm{q}$ and Gas, leading to the activation of phospholipase $\mathrm{C}$ and adenyl cyclase respectively in addition to activating ERK (Razandi et al. 1999). Additionally, ER $\alpha$ directly binds to G $\alpha \mathrm{i}$ and $\mathrm{G} \beta \gamma$ (Kumar et al. 2007). However, some rapid effects of estrogens are transduced by ER-independent pathways (Santen et al. 2009, Yue et al. 2010, Haas et al. 2012, Richardson et al. 2012). Another cell-surface receptor for estrogen has been identified as the orphan $G$ protein-coupled receptor GPR30. Nevertheless, because GPR30 could also transduce the effects of compounds other than estrogens, such as chemokines (Catusse et al. 2010), the concept that GPR30 is an ER remains to be confirmed (Pedram et al. 2006, Levin 2009, Cui et al. 2013). Anyway, little is really known about the participation of GPR30 in effects of estrogens on the thyroid gland, although Vivacqua et al. (2006) have shown that GPR30 mediates the proliferative effect of estrogen in the thyroid cancer cell lines WRO and FRO because knockdown of GPR30 in these cells reduces their estrogen-induced proliferation (Vivacqua et al. 2006).

ER-X, another plasma membrane ER, seems to play a role during development (Toran-Allerand et al. 2002, Cui et al. 2013), but the function of this receptor in postnatal life is still elusive. An additional presumed cell membrane ER is Gq-mER, which binds Gq (Qiu et al. 2003) and seems to mediate estrogen's effects on the hypothalamic control of body temperature and energy homeostasis (Qiu et al. 2006, Roepke et al. 2010).

ER $\alpha$ and ER $\beta$ are expressed in the thyroid of both female and male rats, though female thyroid expresses higher ER levels than male thyroid (Stanley et al. 2010). Estrogen upregulates its own receptor in the thyroid of female and male rats, whereas gonadectomy reduces ER levels in the thyroid of both male and female rats (Banu et al. 2002). Vaiman et al. (2010) have shown that ER $\beta$ is detectable in benign and malignant lesions of human thyroid and also in normal thyroid. However, they did not detect $E R \alpha$ in 296 thyroid tissue samples (150 goiters, 90 papillary carcinomas, 19 follicular adenomas, 15 Hurthle cell adenomas, six Hashimoto's thyroiditis, five anaplastic carcinomas, four medullary carcinomas, four follicular carcinomas, two Hurthle cell carcinomas, and one squamous cell carcinoma of the thyroid) by immunohistochemical analysis (Vaiman et al. 2010). Furthermore, Ceresini et al. (2006) have shown that nuclear ER $\beta$ immunoreactivity is detectable not only in thyroid follicular cells but also in endothelial cells in both multinodular goiter and papillary thyroid carcinoma. Thus, in the human thyroid, ER $\beta$ seems to be the more relevant ER isoform under physiological conditions (Ceresini et al. 2006).

Thyroid cancer is the most common endocrine malignancy. Thyroid neoplasms can be classified as differentiated, which includes papillary and follicular carcinomas; undifferentiated (anaplastic carcinoma); tumors of parafollicular C cells (medullary carcinoma); and poorly differentiated thyroid carcinoma (Salvatore et al. 2011). Molteni et al. (1979) showed that thyroid adenocarcinomas have a high estradiol-binding capacity. The presence of ER was suggested to be higher in neoplastic lesions than in normal tissues (Jaklic et al. 1995), and it apparently decreases with the degree of malignancy (Hiasa et al. 1993, Tavangar et al. 2007), although many authors have not observed this difference (Métayé et al. 1993, Yane et al. 1994). The relationship between ER $\alpha$ and ER $\beta$ seems to differ among different thyroid samples, with lower ER $\beta$-to-ER $\alpha$ mRNA ratios in

Published by Bioscientifica Ltd. 
follicular adenomas compared with normal tissues (Egawa et al. 2001), indicating that the balance between the two ERs might influence thyroid pathogenesis. Zeng et al. (2007) have studied the effect of estradiol on proliferation of thyroid carcinoma cell lines (KAT5, papillary thyroid carcinoma cells and FRO, follicular thyroid carcinoma cells) (Zeng et al. 2007). These authors found that estradiol increased the cell proliferation rate and that this effect was positively correlated with the level of ER $\alpha$ but negatively with that of ER $\beta$. Consistent with these results, Chen et al. (2008b) demonstrated that an ER $\alpha$ agonist stimulates thyroid cancer cell proliferation, whereas an ER $\beta$ agonist reduces it (Chen et al. 2008b). Thus, not only the levels of ER but also the balance between the expression of ER $\alpha$ and ER $\beta$ might affect the action of estrogen on the thyroid gland.

\section{Thyroid function regulation by estrogen}

Estrogen profoundly affects thyroid function, either directly or by regulating the hypothalamus-pituitarythyroid axis. Estrogen increases the thyrotropin (TSH) response to thyrotropin-releasing hormone stimulation in ovariectomized rats (Chen \& Walfish 1978). Additionally, the stimulatory effect of estradiol on thyroid radioiodine uptake in ovariectomized and hypophysectomized rats (Boccabella \& Alger 1964) supports the hypothesis of a direct action of estrogen on the thyroid. Because ERs are expressed in both human and rat thyroid glands (Banu et al. 2002, Arain et al. 2003) and estradiol increases the proliferation rate of the FRTL-5 rat thyroid cell line independent of TSH (Furlanetto et al. 1999), it is clear that this hormone also regulates thyrocytes through a direct action.

Iodide transport is a fundamental step in thyroid hormone synthesis, which is catalyzed by the $\mathrm{Na}^{+} / \mathrm{I}^{-}$ symporter (NIS; Dai et al. 1996, Smanik et al. 1996, Eskandari et al. 1997, Dohan et al. 2003). In FRTL-5 cells, estrogen reduces Nis (Slc5a5) gene expression in the presence of TSH (Furlanetto et al. 1999) and decreases cell iodide uptake in either the presence or the absence of TSH (Furlanetto et al. 2001). However, treatment of both ovariectomized adult and intact prepubertal rats with estrogen significantly increases thyroid iodide uptake (Lima et al. 2006), indicating that in vivo but not in vitro estrogen has a stimulatory effect on NIS. The difference between the two models might be related to the presence of thyroid stromal cells in vivo because these cells express $\mathrm{ER} \alpha$ and $\mathrm{E} \beta$ and could play a role in the thyroid response to estradiol (Gantus et al. 2011).
Thyroperoxidase (TPO) plays a key role in the biosynthesis of thyroid hormones. TPO is a hemecontaining glycoprotein bound to the apical membrane of thyroid cells, which in the presence of $\mathrm{H}_{2} \mathrm{O}_{2}$ catalyzes iodide oxidation, iodination of tyrosyl residues in the thyroglobulin (Tg) molecule, and coupling of iodotyrosines, leading to the formation of thyroid hormones (Ruf \& Carayon 2006). In addition to the fundamental role in thyroid hormone biosynthesis, TPO is also the main thyroid autoantigen, and autoimmune thyroid disease is more frequent in women (Braverman \& Utiger 2000, Bresson et al. 2005). The administration of estradiol to both intact and ovariectomized rats increases TPO activity (Lima et al. 2006), indicating that estrogen stimulates not only thyroid iodide uptake but also iodide organification.

In summary estrogen has a general stimulatory effect on thyroid function, at least in rats, increasing iodide uptake and TPO activity, which would be expected to increase thyroid hormone biosynthesis. However, the effect of estrogen and the consequences of ovariectomy on serum thyroid hormone and TSH concentrations are controversial and seem to depend on the model used (Böttner \& Wuttke 2005, Seidlová-Wuttke et al. 2005, Sosić-Jurjević et al. 2005, Lima et al. 2006, Marassi et al. 2007, Abdel-Dayem \& Elgendy 2009, Pantaleão et al. 2010). In addition, estrogen increases thyroxine-binding globulin (TBG) production both in vivo in women (Dowling et al. 1956, Robbins \& Nelson 1958, Doe et al. 1967) and in vitro by hepatocytes of Rhesus monkeys (Glinoer et al. 1977). Thus, it is difficult to make a clear distinction between increases in serum thyroid hormone levels induced by estrogen directly, by increasing thyroid function, or indirectly, through an increase in TBG levels.

\section{NADPH oxidases and thyroid physiology}

Thyrocytes produce large amounts of $\mathrm{H}_{2} \mathrm{O}_{2}$ during their lives. At the apical membrane of thyrocytes, $\mathrm{H}_{2} \mathrm{O}_{2}$ acts as a TPO cosubstrate in thyroid hormone biosynthesis and is produced by calcium-dependent NADPH oxidases (NOX), namely dual oxidase (DUOX) (Dupuy et al. 1999, De Deken et al. 2000, Ameziane-El-Hassani et al. 2005). The NOX/DUOX family is composed of seven members, NOX1-NOX5 and DUOX1/2, which are differentially expressed among tissues (Weyemi \& Dupuy 2012). The biological roles of NOXs are quite diverse, but the first physiological function described was related to the immune response, as NOX2 is activated during the neutrophil respiratory burst. However, other processes, such as cellular proliferation, apoptosis inhibition,

Published by Bioscientifica Ltd 
calcium release, and hormone biosynthesis, are well documented (Berdad \& Krause 2007). Thyrocytes express both DUOX1 and DUOX2 at the apical membrane, but the source of $\mathrm{H}_{2} \mathrm{O}_{2}$ that sustains production of thyroid hormones (TH) seems to be DUOX2. The evidence that supports this idea is that mutations in Duox2, but not in Duox1, are associated with congenital hypothyroidism, and that mice deficient in Duox2, but not Duox1, are hypothyroid (Johnson et al. 2007, Donkó et al. 2010, Grasberger 2010). Both DUOX enzymes need the presence of their corresponding maturation factor, called DUOXA, to exit the endoplasmic reticulum and reach the apical plasma membrane (Grasberger \& Refetoff 2006), where these proteins form stable complexes at the cell surface that are essential for DUOX activity (Morand et al. 2009). NOX4 is also present in thyrocytes, but it is localized intracellularly, specifically in endoplasmic reticulum and the nuclear membrane, and does not seem to be involved in TH biosynthesis (Weyemi et al. 2010). In contrast to DUOX enzymes, which need the presence of DUOXA for their activity, NOX4 seems to be more active in the presence of p22phox or possibly Poldip2 (Lyle et al. 2009), but this enzyme is constitutively active. NOX4 is detected in the nuclear or perinuclear regions of the cells and most probably acts as an intracellular signaling oxidase (Leto et al. 2009) (Fig. 1).

\section{ROS and thyroid pathophysiology}

As $\mathrm{H}_{2} \mathrm{O}_{2}$ is a ROS and might thus react with cellular components such as lipids, proteins, and DNA, some authors argue that $\mathrm{H}_{2} \mathrm{O}_{2}$ generated for TH biosynthesis could be toxic to thyrocytes. Maier et al. (2006) showed that the rat thyroid gland has a high level of DNA oxidative damage in comparison with other tissues, such as liver, spleen, and lung, indicating that the high frequency of somatic mutations and tumor initiation found in this organ is due to the oxidative environment that thyroid cells are subjected to during their long lives (Maier et al. 2006). In addition, carcinogenic effects of $\mathrm{H}_{2} \mathrm{O}_{2}$ on thyrocytes have been clearly demonstrated in two different in vitro studies. When a rat thyroid cell

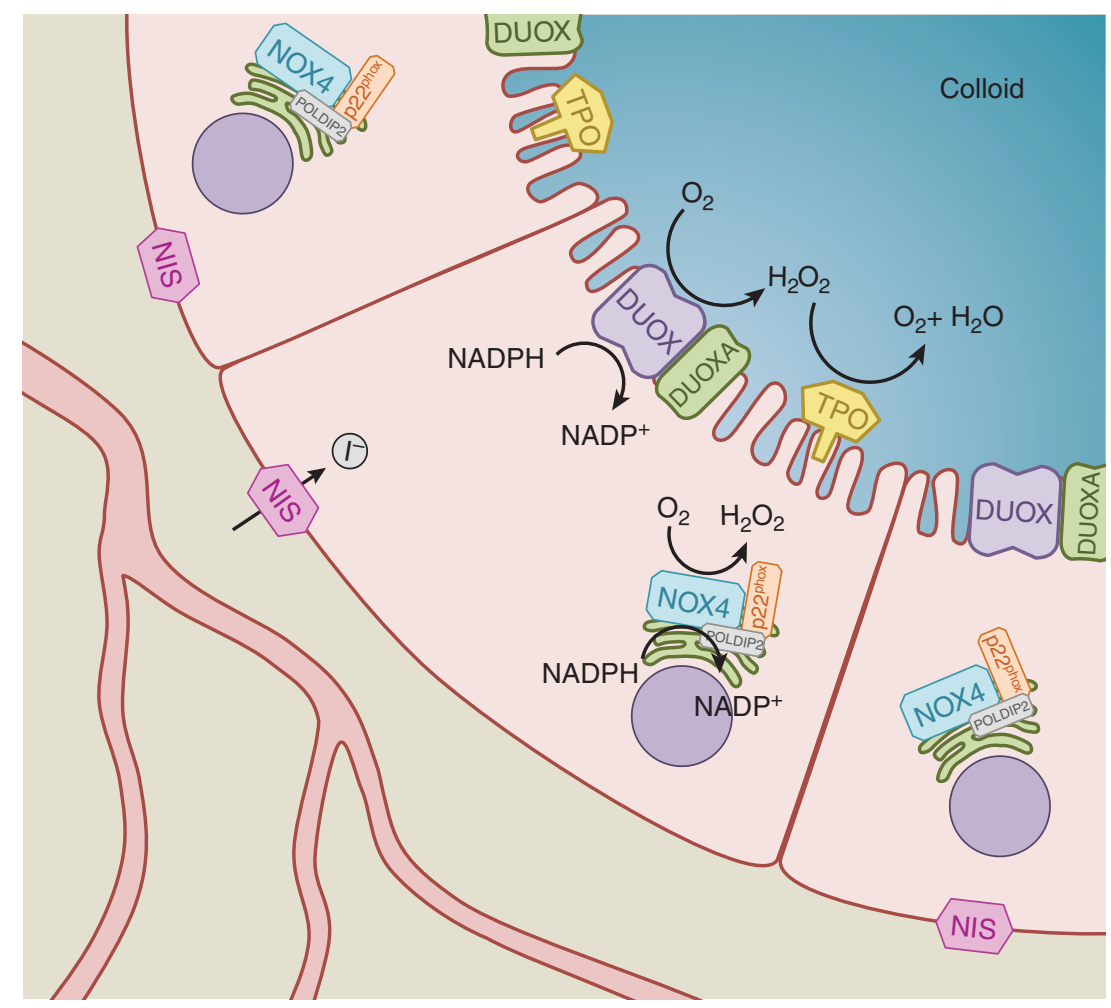

Figure 1

NADPH oxidase (NOX) enzymes expressed in the thyroid gland. DUOX-derived $\mathrm{H}_{2} \mathrm{O}_{2}$ is used as a cosubstrate by thyroperoxidase (TPO) for thyroid hormone biosynthesis at the apical membrane of thyrocytes. NOX4 produces ROS in intracellular compartments. NAPDH, NAD; NADP+,
NADH; DUOX, dual oxidase; DUOXA, dual oxidase maturation factor; NIS, sodium/iodide symporter; POLDIP2, polymerase delta-interacting protein 2; ROS, reactive oxygen species. http://joe.endocrinology-journals.org DOI: 10.1530/JOE-13-0588
() 2014 Society for Endocrinology Printed in Great Britain 
line (PCCL3) was incubated with nonlethal $\mathrm{H}_{2} \mathrm{O}_{2}$ concentrations, the numbers of single- and double-strand breaks in DNA increased, as did the phosphorylation of histone H2AX, a marker of double-strand breaks (Driessens et al. 2009). Moreover, $\mathrm{H}_{2} \mathrm{O}_{2}$ exposure induced RET/PTC rearrangement formation in a human thyroid cell line, which was abolished when catalase was added to the incubation medium (Ameziane-El-Hassani et al. 2010).

In fact, any disturbance in ROS generation or consumption will promote ROS accumulation that can contribute to thyroid dysfunction. In this context, it is important to note that the site of ROS formation is closely linked to the type and extent of the damage. This can be explained by the short half-life of ROS molecules due to their high reactivity and the presence of antioxidant mechanisms in the whole cell (Block \& Gorin 2012). DUOX enzymes are localized at the apical membrane of thyrocytes, physically and functionally interacting with $\mathrm{TPO}$, and creating a producer-consumer unit that restricts the amount of $\mathrm{H}_{2} \mathrm{O}_{2}$ released into the lumen of follicular cells (Fortunato et al. 2010, Song et al. 2010). Furthermore, glutathione peroxidase 3 (GPx3), also located in the apical cell surface, and other intracellular antioxidant enzymes and molecules, such as GPx1, superoxide dismutase, catalase, and peroxiredoxins, most probably destroy $\mathrm{H}_{2} \mathrm{O}_{2}$ before it can react with DNA in the nucleus (Schweizer et al. 2008). On the other hand, NOX4 is an intracytoplasmatic ROS-generating enzyme, possibly located at the endoplasmic reticulum, and nuclear membrane where it was recently found in other cell types (Chen et al. 2008a,b, Weyemi et al. 2010, Spencer et al. 2011). Thus, $\mathrm{H}_{2} \mathrm{O}_{2}$ released by NOX 4 can be linked to genomic instability.

We have previously compared DUOX and TPO activity in hypofunctioning thyroid lesions, and we found a negative correlation between these enzyme activities (Ginabreda et al. 2008). $\mathrm{H}_{2} \mathrm{O}_{2}$ can oxidize many proteins, changing their functions. Therefore, we proposed the hypothesis that $\mathrm{H}_{2} \mathrm{O}_{2}$ produced by DUOX could oxidize TPO, changing its activity, once both proteins are colocalized at the plasma membrane. Utilizing a heterologous system, we showed that indeed, $\mathrm{H}_{2} \mathrm{O}_{2}$ produced by DUOX reacts with TPO, decreasing its activity (Fortunato et al. 2010).

It has been suggested that ROS can contribute to autoimmune thyroid diseases, such as Hashimoto's thyroiditis and Graves' disease (Burek \& Rose 2008). Tg and TPO are major autoantigens involved in autoimmune diseases (McIntosh \& Weetman 1997). Tg fragmentation can occur during iodination and coupling of tyrosine residues in $\mathrm{TH}$ biosynthesis, forming immunoreactive peptides. Interestingly, it seems that $\mathrm{Tg}$ cleavage is a reaction that involves $\mathrm{H}_{2} \mathrm{O}_{2}$ produced in the apical membrane of thyrocytes (Duthoit et al. 2000, Raad et al. 2013). Raad et al. (2013) studied the effects of the main cytokines involved in Hashimoto's thyroiditis and Graves' disease, interferon $\gamma$ (IFN- $\gamma$ ) and IL4/IL13 respectively, on DUOX expression and activity. IL4 and IL13 increase DUOX2 and DUOXA2 expression and calcium-dependent $\mathrm{H}_{2} \mathrm{O}_{2}$ generation, and IFN- $\gamma$ treatment inhibits DUOX gene expression and blocks induction of Th2 by DUOX2/ DUOXA2 (Raad et al. 2013). Taken together, the findings mentioned above indicate that DUOX enzymes could be involved in thyroid autoimmune pathophysiology.

Some studies have shown increases in peroxide content, lipid peroxidation, and the activity of the antioxidant enzyme catalase and GPx during goitrogenesis in rats (Poncin et al. 2008, Thomasz et al. 2010). The source of ROS during goitrogenesis has not been demonstrated, but NOX4 is a good candidate, according to recent findings. In the thyroid, NOX4 is present in activated, tall columnar cells and absent in quiescent, flat cells, indicating a role in thyrocyte functional activity. It is important to note that NOX4 and p22phox mRNA levels, as well as intracellular ROS generation, increase in a dosedependent manner when human thyrocytes are incubated with TSH, indicating that ROS produced by NOX4 can act as second messengers in TSH signaling, as they do in other models (Weyemi et al. 2010).

A pro-oxidative environment can be involved in all steps related to carcinogenesis, such as initiation, promotion, and progression (Scandalios 2005). The main function of NOX is ROS production. Therefore, changes in NOX expression and/or activity could be related to carcinogenesis. ROS can directly interact with cellular macromolecules, such as nucleic acids leading to nucleotide oxidation and single- and double-strand breaks, thereby promoting genomic instability. However, a wide range of signaling pathways are redox-sensitive, so an increase in ROS can modulate autonomous cell growth and immortality (Block \& Gorin 2012). Some previous studies evaluated DUOX expression and activity in samples of thyroid carcinomas, but no significant differences in the activity or expression of these enzymes were detected between normal and cancerous tissues (Lacroix et al. 2001, Ginabreda et al. 2008). In this context, NOX4 has gained attention in thyroid pathophysiology because its expression is higher in thyroid tumors in comparison with normal tissue. In fact, normal thyroid cells overexpressing an activated Ras oncogene

Published by Bioscientifica Ltd. 
have increased NOX4 expression and activity, which is implicated in the stimulation of the DNA replication rate and DNA damage, leading to cellular senescence (Weyemi et al. 2012).

\section{Estrogen effects on thyroid redox balance}

A large body of evidence correlates different thyroid dysfunctions with redox imbalance, generally due to NOX activation. Our group proposed that the higher prevalence of thyroid diseases in women could be, at least in part, due to sex-related differences in the thyroid redox environment. Utilizing rats as a model, we have shown higher $\mathrm{H}_{2} \mathrm{O}_{2}$ production and $\mathrm{NOX} 4$ expression in the thyroid of adult female rats in comparison with their male counterparts, but not in prepubertal animals, in which serum estradiol concentration is not significantly different between sexes (Fortunato et al. 2013). Weyemi et al. (2010) reported that in normal human thyroid tissue, NOX4 immunostaining is intracytoplasmic (Weyemi et al. 2010). However, although we confirmed that NOX4 immunostaining in the thyroids of both male

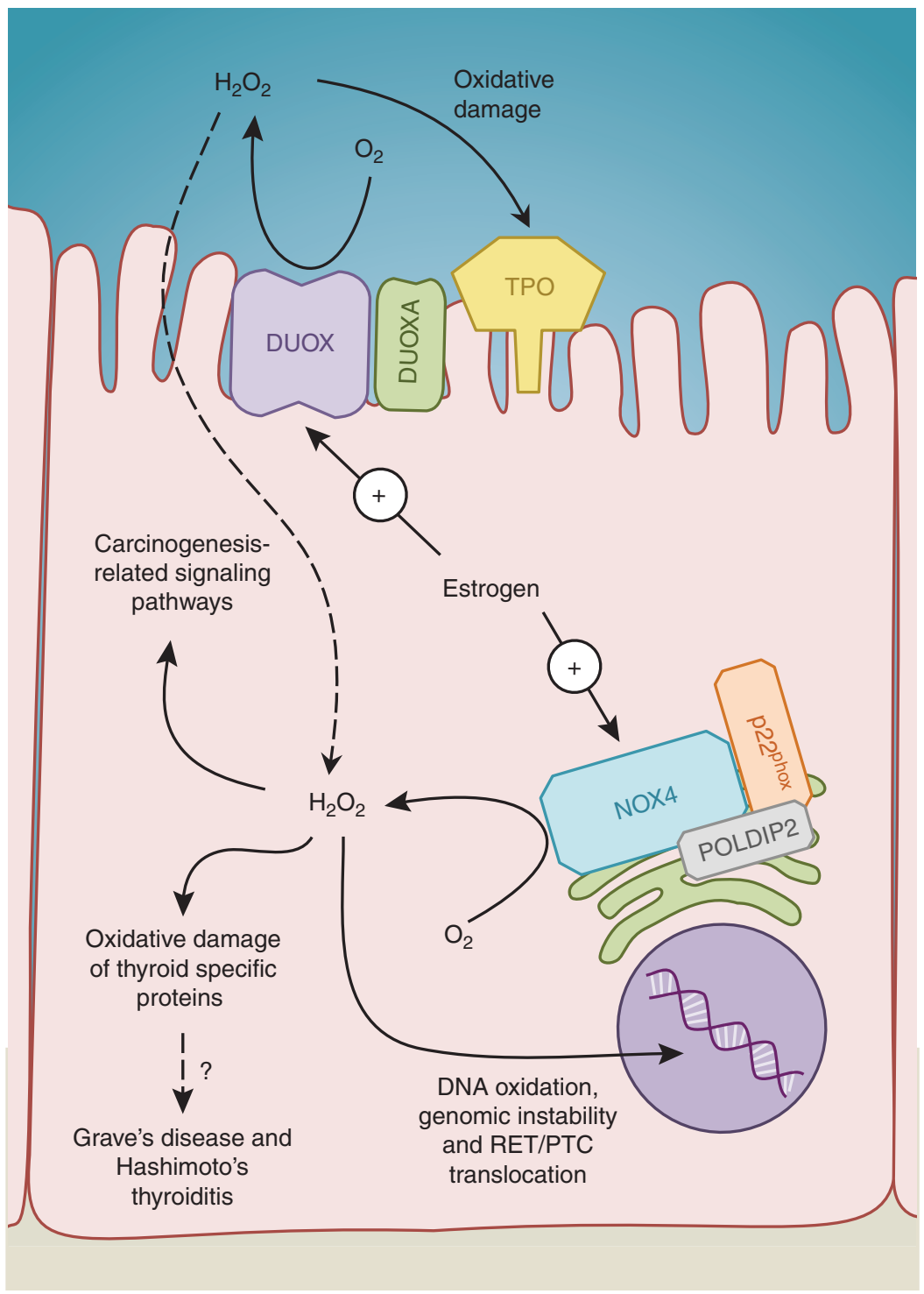

\section{Figure 2}

A hypothesis for thyroid dysfunctions related to estrogen exposure through NADPH oxidase activation. Estrogen signaling activates the production of ROS by NOX4 and DUOX in the thyroid tissue and may contribute to the establishment of an environment prone to the development of cancer and/or autoimmune disorders. DUOX, dual oxidase; DUOXA, dual oxidase maturation factor; NOX4, NAPDH oxidase 4; POLDIP2, polymerase delta-interacting protein 2; ROS, reactive oxygen species; TPO, thyroperoxidase.

Published by Bioscientifica Ltd. 
and female rats is intracytoplasmic, we have also detected NOX4 immunostaining at the plasma membrane of thyrocytes. Furthermore, we have found higher NOX4 expression in the thyroid of female rats in the proestrus phase of the estrous cycle (characterized by an estrogen peak) and higher NOX4 expression and $\mathrm{H}_{2} \mathrm{O}_{2}$ production in PCCL3 cells treated with $17 \beta$-estradiol, indicating a role for estrogen in this process. DUOX2 was not different when we compared the thyroids from male and female rats, but estrogen also increased DUOX2 expression both in vivo and in vitro (unpublished data). In addition, catalase expression and activity, together with levels of thiol groups, were lower in adult female thyroid (Fortunato et al. 2013). Taken together, these results show sex-related differences in thyroid redox balance, with increased ROS production and decreased antioxidant defense in female thyroid (Fig. 2).

Although we have demonstrated the stimulatory effect of estrogen on NOX4 expression and activity, some questions remain to be elucidated. How could NOX4 be involved in estrogen-related thyroid dysfunction? First of all, because NOX4 is located intracellularly, the $\mathrm{H}_{2} \mathrm{O}_{2}$ produced by the enzyme could cause genomic instability through its reaction with cellular DNA. Cells overexpressing activated Ras oncogene have increased NOX4 expression and activity, which is responsible for the stimulation of DNA replication and DNA damage, leading to cellular senescence (Weyemi et al. 2012). In contrast, NOX4 and DUOX2 seem to regulate cell cycle entry via the p53-dependent pathway. PDGF-induced proliferation in HS68 fibroblast cells is abolished after NOX4 or DUOX2 knockdown, due to reduced ERK1 phosphorylation and increased levels of p53 and the cell cycle inhibitor protein p21 (Salmeen et al. 2010). It is important to note that estradiol is able to induce proliferation in normal and cancerous thyroid cells through ERK1/2 phosphorylation, so $\mathrm{H}_{2} \mathrm{O}_{2}$ produced by $\mathrm{NOX} 4$ could be involved in this signaling pathway (Manole et al. 2001, Kumar et al. 2010). Vascular endothelial growth factor (VEGF) is a proangiogenic factor with a central role in the function, development, and growth of blood vessels. Thyroid VEGF is upregulated by estrogen, and thyroid weight, vascular area, and VEGF protein expression are lower in ovariectomized rats in comparison with sham-operated rats and ovariectomized rats treated with $17 \beta$-estradiol (de Araujo et al. 2010). Interestingly, in PCCL3 cells, an increase in intracellular ROS, elicited by iodide deprivation, induces HIF- $1 \alpha$ and VEGF protein expression, but concomitant treatment with the antioxidant $\mathrm{N}$-acetyl-cysteine abolishes the effects of iodide deprivation (Gérard et al.
2009). Thus, it is tempting to speculate that NOX4 could also be involved in the regulation of thyroid VEGF expression induced by estradiol and iodide deprivation.

\section{Summary and conclusions}

In this review, we propose that ROS could be involved in the sexual dimorphism found in thyroid dysfunctions. Future studies are necessary to evaluate the involvement of NOX4-generated ROS in the estrogen-signaling pathway in thyrocytes. Elucidating this issue is crucial to improving our knowledge of the mechanisms involved in thyroid pathophysiology and will allow us to determine whether NOXs are potential therapeutic targets for thyroid dysfunctions.

\section{Declaration of interest}

The authors declare that there is no conflict of interest that could be perceived as prejudicing the impartiality of the review.

\section{Funding}

This work was supported by the Fundação Carlos Chagas Filho de Amparo a Pesquisa à Pesquisa do Rio de Janeiro (E-26/110.917/2013).

\section{References}

Abdel-Dayem MM \& Elgendy MS 2009 Effects of chronic estradiol treatment on the thyroid gland structure and function of ovariectomized rats. BMC Research Notes 2 173. (doi:10.1186/ 1756-0500-2-173)

Ameziane-El-Hassani R, Morand S, Boucher JL, Frapart YM, Apostolou D, Agnandji D, Gnidehou S, Ohayon R, Noël-Hudson MS, Francon J et al. 2005 Dual oxidase-2 has an intrinsic $\mathrm{Ca}^{2+}$-dependent $\mathrm{H}_{2} \mathrm{O}_{2}$-generating activity. Journal of Biological Chemistry 280 30046-30054. (doi:10.1074/ jbc.M500516200)

Ameziane-El-Hassani R, Boufraqech M, Lagente-Chevallier O, Weyemi U, Talbot M, Métivier D, Courtin F, Bidart JM, El Mzibri M, Schlumberger $\mathrm{M}$ et al. 2010 Role of $\mathrm{H}_{2} \mathrm{O}_{2}$ in RET/PTC1 chromosomal rearrangement produced by ionizing radiation in human thyroid cells. Cancer Research 70 4123-4132. (doi:10.1158/0008-5472.CAN-09-4336)

Arain SA, Shah MH, Meo SA \& Jamal Q 2003 Estrogen receptors in human thyroid gland. An immunohistochemical study. Saudi Medical Journal 24 174-178.

de Araujo LF, Grozovsky R, dos Santos Pereira MJ, de Carvalho JJ, Vaisman M \& Carvalho DP 2010 Expressions of vascular endothelial growth factor and nitric oxide synthase III in the thyroid gland of ovariectomized rats are upregulated by estrogen and selective estrogen receptor modulators. Thyroid 20 85-92. (doi:10.1089/thy.2009.0246)

Banu SK, Govindarajulu P \& Aruldhas MM 2002 Testosterone and estradiol up-regulate androgen and estrogen receptors in immature and adult rat thyroid glands in vivo. Steroids 67 1007-1014. (doi:10.1016/S0039128X(02)00063-6)

Berdad K \& Krause KH 2007 The NOX family of ROS-generating NADPH oxidases: physiology and pathophysiology. Physiological Reviews $\mathbf{8 7}$ 245-313. (doi:10.1152/physrev.00044.2005) http://joe.endocrinology-journals.org DOI: $10.1530 / J O E-13-0588$
C 2014 Society for Endocrinology Printed in Great Britain 
Block K \& Gorin Y 2012 Aiding and abetting roles of NOX oxidases in cellular transformation. Nature Reviews. Cancer 12 627-637. (doi:10.1038/nrc3339)

Boccabella AV \& Alger EA 1964 Influence of estradiol on thyroid: serum radioiodine concentration ratios of gonadectomized and hypophysectomized rats. Endocrinology 74 680-688. (doi:10.1210/endo-74-5-680)

Böttner M \& Wuttke W 2005 Chronic treatment with low doses of estradiol affects pituitary and thyroid function in young and middle-aged ovariectomized rats. Biogerontology 6 261-269. (doi:10.1007/s10522005-2623-2)

Braverman LE \& Utiger RD 2000 Introduction to hypothyroidism. In The Thyroid: a Fundamental and Clinical Text, 8th edn, pp 61-84. Eds LE Braverman \& RD Utiger. New York: Lippincott-Raven.

Brent GA \& Davies TF 2011 Hypothyroidism and thyroiditis. In Williams Textbook of Endocrinology, 12th edn, pp 406-439. Eds S Melmed, KS Polonsky, PR Larsen \& HM Kronemberg. Philadelphia: W.B. Saunders Company.

Bresson D, Rebuffat SA, Nguyen B, Banga JP, Gardas A \& Peraldi-Roux S 2005 New insights into the conformational dominant epitopes on thyroid peroxidase recognized by human autoantibodies. Endocrinology 146 2834-2844. (doi:10.1210/en.2005-0038)

Burek CL \& Rose NR 2008 Autoimmune thyroiditis and ROS. Autoimmunity Reviews 7 530-537. (doi:10.1016/j.autrev.2008.04.006)

Catusse J, Wollner S, Leick M, Schröttner P, Schraufstätter I \& Burger M 2010 Attenuation of CXCR4 responses by CCL18 in acute lymphocytic leukemia B cells. Journal of Cellular Physiology 225 792-800. (doi:10.1002/jcp.22284)

Ceresini G, Morganti S, Graiani V, Saccani M, Milli B, Usberti E, Valenti G, Ceda GP \& Corcione L 2006 Estrogen receptor (ER)- $\beta$, but not ER- $\alpha$, is present in thyroid vessels: immunohistochemical evaluations in multinodular goiter and papillary thyroid carcinoma. Thyroid $\mathbf{1 6}$ 1215-1220. (doi:10.1089/thy.2006.16.1215)

Chen HJ \& Walfish PG 1978 Effects of estradiol benzoate on thyroidpituitary function in female rats. Endocrinology 103 1023-1030. (doi:10.1210/endo-103-4-1023)

Chen K, Kirber MT, Xiao H, Yang Y \& Keaney JF Jr 2008a Regulation of ROS signal transduction by NADPH oxidase 4 localization. Journal of Cell Biology 181 1129-1139. (doi:10.1083/jcb.200709049)

Chen GG, Vlantis AC, Zeng Q \& van Hasselt CA 2008b Regulation of cell growth by estrogen signaling and potential targets in thyroid cancer. Current Cancer Drug Targets 8 367-377. (doi:10.2174/ 156800908785133150

Couse JF \& Korach KS 1999 Estrogen receptor null mice: what have we learned and where will they lead us? Endocrine Reviews 20 358-417. (doi:10.1210/edrv.20.3.0370)

Cui J, Shen Y \& Li R 2013 Estrogen synthesis and signaling pathways during aging: from periphery to brain. Trends in Molecular Medicine 19 197-209. (doi:10.1016/j.molmed.2012.12.007)

Dai G, Levy O \& Carrasco N 1996 Cloning and characterization of the thyroid iodide transporter. Nature 379 485-460. (doi:10.1038/ 379458a0)

De Deken X, Wang D, Many MC, Costagliola S, Libert F, Vassart G, Dumont JE \& Miot F 2000 Cloning of two human thyroid cDNAs encoding new members of the NADPH oxidase family. Journal of Biological Chemistry 275 23227-23233. (doi:10.1074/jbc.M000916200)

Doe RP, Mellinger GT, Swaim WR \& Seal US 1967 Estrogen dosage effects on serum proteins: a longitudinal study. Journal of Clinical Endocrinology and Metabolism 27 1081-1086. (doi:10.1210/jcem-27-8-1081)

Dohan O, Vieja A, Paroder V, Riedel C, Artani M, Reed M, Ginter CS \& Carrasco N 2003 The sodium/iodide symporter (NIS): characterization, regulation, and medical significance. Endocrine Reviews 24 48-77. (doi:10.1210/er.2001-0029)

Donkó A, Ruisanchez E, Orient A, Enyedi B, Kapui R, Péterfi Z, de Deken X, Benyó Z \& Geizt M 2010 Urothelial cells produce hydrogen peroxide through the activation of Duox1. Free Radical Biology \& Medicine 49 2040-2048. (doi:10.1016/j.freeradbiomed.2010.09.027)

http://joe.endocrinology-journals.org DOI: $10.1530 / J O E-13-0588$
() 2014 Society for Endocrinology Printed in Great Britain
Dowling JT, Freinkel N \& Ingbar SH 1956 Effect of diethylstilbestrol on the binding of thyroxine in serum. Journal of Clinical Endocrinology and Metabolism 16 1491-1506. (doi:10.1210/jcem-16-11-1491)

Driessens N, Versteyhe S, Ghaddhab C, Burniat A, De Deken X, Van Sande J, Dumont JE, Miot F \& Corvilain B 2009 Hydrogen peroxide induces DNA single- and double-strand breaks in thyroid cells and is therefore a potential mutagen for this organ. Endocrine-Related Cancer 16 845-856. (doi:10.1677/ERC-09-0020)

Dupuy C, Ohayon R, Valent A, Noel-Hudson MS, Deme D \& Virion A 1999 Purification of a novel flavoprotein involved in the thyroid NADPH oxidase. Cloning of the porcine and human cDNAs. Journal of Biological Chemistry 274 37265-37269. (doi:10.1074/jbc.274.52.37265)

Duthoit C, Estienne V, Delom F, Durand-Gorde JM, Mallet B, Carayon P \& Ruf J 2000 Production of immunoreactive thyroglobulin C-terminal fragments during thyroid hormone synthesis. Endocrinology 141 2518-2525. (doi:10.1210/endo.141.7.7573)

Egawa C, Miyoshi Y, Iwao K, Shiba E \& Noguchi S 2001 Quantitative analysis of estrogen receptor- $\alpha$ and $-\beta$ messenger RNA expression in normal and malignant thyroid tissues by real-time polymerase chain reaction. Oncology 61 293-298. (doi:10.1159/000055336)

Eskandari S, Loo DDF, Dai G, Levy O, Wright EM \& Carrasco N 1997 Thyroid $\mathrm{Na}^{+} / \mathrm{I}^{-}$symporter - mechanism, stoichiometry, and specificity. Journal of Biological Chemistry 272 27230-27238. (doi:10.1074/jbc.272.43.27230)

Fortunato RS, Lima de Souza EC, Ameziane-el Hassani R, Boufraqech M, Weyemi U, Talbot M, Lagente-Chevallier O, de Carvalho DP, Bidart JM, Schlumberger M et al. 2010 Functional consequences of dual oxidasethyroperoxidase interaction at the plasma membrane. Journal of Clinical Endocrinology and Metabolism 95 5403-5411. (doi:10.1210/jc.20101085)

Fortunato RS, Braga WMO, Ortenzi VH, Rodrigues DC, Andrade BM, Miranda-Alves L, Rondinelli E, Dupuy C, Ferreira ACF \& Carvalho DP 2013 Sexual dimorphism of thyroid reactive oxygen species production due to higher NADPH oxidase 4 expression in female thyroid glands. Thyroid 23 111-119. (doi:10.1089/thy.2012.0142)

Furlanetto TW, Nguyen LQ \& Jameson JL 1999 Estradiol increases proliferation and down-regulates the sodium/ iodide symporter gene in FRTL-5. Endocrinology 140 5705-5711. (doi:10.1210/endo.140.12.7197)

Furlanetto TW, Nunes RB Jr, Sopelsa AM \& Maciel RM 2001 Estradiol decreases iodide uptake by rat thyroid follicular FRTL-5 cells. Brazilian Journal of Medical and Biological Research 34 259-263. (doi:10.1590/ S0100-879X2001000200015)

Gantus MA, Alves LM, Stipursky J, Souza EC, Teodoro AJ, Alves TR, Carvalho DP, Martinez AM, Gomes FC \& Nasciutti LE 2011 Estradiol modulates TGF- $\beta 1$ expression and its signaling pathway in thyroid stromal cells. Molecular and Cellular Endocrinology 337 71-79. (doi:10.1016/j.mce.2011.02.001)

Gérard AC, Poncin S, Audinot JN, Denef JF \& Colin IM 2009 Iodide deficiency-induced angiogenic stimulus in the thyroid occurs via HIF- and ROS-dependent VEGF-A secretion from thyrocytes. American Journal of Physiology. Endocrinology and Metabolism 296 E1414-E1422. (doi:10.1152/ajpendo.90876.2008)

Ginabreda MG, Cardoso LC, Nobrega FM, Ferreira AC, Gonçalves MD, Vaisman M \& Carvalho DP 2008 Negative correlation between thyroperoxidase and dual oxidase $\mathrm{H}_{2} \mathrm{O}_{2}$-generating activities in thyroid nodular lesions. European Journal of Endocrinology 158 223-227. (doi:10.1530/EJE-07-0602)

Glinoer D, McGuire RA, Gershengorn MC, Robbins J \& Berman M 1977 Effects of estrogen on thyroxine-binding globulin metabolism in rhesus monkeys. Endocrinology 100 9-17. (doi:10.1210/endo-100-1-9)

Grasberger H 2010 Defects of thyroidal hydrogen peroxide generation in congenital hypothyroidism. Molecular and Cellular Endocrinology $\mathbf{3 2 2}$ 99-106. (doi:10.1016/j.mce.2010.01.029)

Grasberger H \& Refetoff S 2006 Identification of the maturation factor for dual oxidase. Evolution of an eukaryotic operon equivalent. Journal of Biological Chemistry 281 18269-18272. (doi:10.1074/jbc.C600095200)

Published by Bioscientifica Ltd. 
Green S, Walter P, Kumar V, Krust A, Bornert JM, Argos P \& Chambon P 1986 Human oestrogen receptor cDNA: sequence, expression and homology to v-erb-A. Nature 320 134-139. (doi:10.1038/320134a0)

Haas MJ, Raheja P, Jaimungal S, Sheikh-Ali M \& Mooradian AD 2012 Estrogen-dependent inhibition of dextrose-induced endoplasmic reticulum stress and superoxide generation in endothelial cells. Free Radical Biology \& Medicine 52 2161-2167. (doi:10.1016/j.freeradbiomed. 2012.04.009)

Hampl R, Němec J, Heresová J, Kimlová I \& Stárka L 1985 Estrogen receptors in human goitrous and neoplastic thyroid. Endocrinologia Experimentalis 19 227-230.

Hiasa Y, Nishioka H, Kitahori Y, Yane K, Nakaoka S, Ohshima M, Konishi N, Nishii K, Kitamura M \& Matsunaga T 1993 Immunohistochemical analysis of estrogen receptors in 313 paraffin section cases of human thyroid tissue. Oncology 50 132-136. (doi:10.1159/000227164)

Hollowell JG, Staehling NW, Flanders WD, Hannon WH, Gunter EW, Spencer CA \& Braverman LE 2002 Serum TSH, T 4 , and thyroid antibodies in the United States population (1988 to 1994): National Health and Nutrition Examination Survey (NHANES III). Journal of Clinical Endocrinology and Metabolism 87 489-499. (doi:10.1210/jcem. 87.2.8182)

Jaklic BR, Rushin J \& Ghosh BC 1995 Estrogen and progesterone receptors in thyroid lesions. Annals of Surgical Oncology 2 429-434. (doi:10.1007/ BF02306376)

Johnson KR, Marden CC, Ward-Bailey P, Gagnon LH, Bronson RT \& Donahue LR 2007 Congenital hypothyroidism, dwarfism, and heariong impairment caused by a missence mutation in the mouse dual oxidase 2 gene, Duox2. Molecular Endocrinology 21 1593-1602. (doi:10.1210/me. 2007-0085)

Kumar P, Wu Q, Chambliss KL, Yuhanna IS, Mumby SM, Mineo C, Tall GG \& Shaul PW 2007 Direct interactions with $G \alpha$ i and G $\beta \gamma$ mediate nongenomic signaling by estrogen receptor $\alpha$. Molecular Endocrinology 21 1370-1380. (doi:10.1210/me.2006-0360)

Kumar A, Klinge CM \& Goldstein RE 2010 Estradiol-induced proliferation of papillary and follicular thyroid cancer cells is mediated by estrogen receptors $\alpha$ and $\beta$. International Journal of Oncology 36 1067-1080. (doi:10.3892/ijo_00000629)

Lacroix L, Nocera M, Mian C, Caillou B, Virion A, Dupuy C, Filetti S, Bidart JM \& Schlumberger M 2001 Expression of nicotinamide adenine dinucleotide phosphate oxidase flavoprotein DUOX genes and proteins in human papillary and follicular thyroid carcinomas. Thyroid $\mathbf{1 1}$ 1017-1023. (doi:10.1089/105072501753271699)

Leto TL, Morand S, Hurt D \& Ueyama T 2009 Targeting and regulation of reactive oxygen species generation by Nox family NADPH oxidases. Antioxidants \& Redox Signaling 11 2607-2619. (doi:10.1089/ars.2009. 2637)

Levin ER 2009 Plasma membrane estrogen receptors. Trends in Endocrinology and Metabolism 20 477-482. (doi:10.1016/j.tem.2009.06.009)

Lima LP, Barros IA, Lisbôa PC, Araújo RL, Silva AC, Rosenthal D, Ferreira AC \& Carvalho DP 2006 Estrogen effects on thyroid iodide uptake and thyroperoxidase activity in normal and ovariectomized rats. Steroids $\mathbf{7 1}$ 653-659. (doi:10.1016/j.steroids.2006.03.007)

Lyle AN, Deshpande NN, Taniyama Y, Seidel-Rogol B, Pounkova L, Du P, Papaharalambus C, Lassègue B \& Griendling KK 2009 Poldip2, a novel regulator of Nox4 and cytoskeletal integrity in vascular smooth muscle cells. Circulation Research 105 249-259. (doi:10.1161/CIRCRESAHA. 109.193722)

Maier J, van Steeg H, van Oostrom C, Karger S, Paschke R \& Krohn K 2006 Deoxyribonucleic acid damage and spontaneous mutagenesis in the thyroid gland of rats and mice. Endocrinology 147 3391-3397. (doi:10.1210/en.2005-1669)

Mandel SJ, Larsen PR \& Davies TF 2011 Thyrotoxicosis. In Williams Textbook of Endocrinology, 12th edn, pp 362-405. Eds S Melmed, KS Polonsky, PR Larsen \& HM Kronemberg. Philadelphia: W.B. Saunders Company.
Mangelsdorf DJ, Thummel C, Beato M, Herrlich P, Schütz G, Umesono K, Blumberg B, Kastner P, Mark M, Chambon P et al. 1995 The nuclear receptor superfamily: the second decade. Cell 83 835-839. (doi:10.1016/0092-8674(95)90199-X)

Manole D, Schildknecht B, Gosnell B, Adams E \& Derwahl M 2001 Estrogen promotes growth of human thyroid tumor cells by different molecular mechanisms. Journal of Clinical Endocrinology and Metabolism 86 1072-1077. (doi:10.1210/jcem.86.3.7283)

Marassi MP, Fortunato RS, da Silva AC, Pereira VS, Carvalho DP, Rosenthal D \& da Costa VM 2007 Sexual dimorphism in thyroid function and type 1 iodothyronine deiodinase activity in pre-pubertal and adult rats. Journal of Endocrinology 192 121-130. (doi:10.1677/joe. 1.06901)

Marino M, Galluzzo P \& Ascenzi P 2006 Estrogen signaling multiple pathways to impact gene transcription. Current Genomics 7 497-508. (doi:10.2174/138920206779315737)

McIntosh RE \& Weetman AP 1997 Molecular analysis of the antibody response, to thyroglobulin and thyroid peroxidase. Thyroid 7 471-487. (doi:10.1089/thy.1997.7.471)

Métayé T, Millet C, Kraimps JL, Aubouin B, Barbier J \& Bégon F 1993 Estrogen receptors and cathepsin D in human thyroid tissue. Cancer 72 1991-1996. (doi:10.1002/1097-0142(19930915)72:6\%3C;1991::AIDCNCR2820720633\%3E;3.0.CO;2-M)

Molteni A, Bahu RM, Battifora HA, Fors EM, Reddy JK, Rao MS \& Scarpelli DG 1979 Estradiol receptor assays in normal and neoplastic tissues. A possible diagnostic acid for tumor differentiation. Annals of Clinical Laboratory Science 9 103-108.

Morand S, Ueyama T, Tsujibe S, Saito N, Korzeniowska A \& Leto TL 2009 Duox maturation factors form cell surface complexes with Duox affecting the specificity of reactive oxygen species generation. FASEB Journal 23 1205-1218. (doi:10.1096/fj.08-120006)

Pantaleão TU, Mousovich F, Rosenthal D, Padrón AS, Carvalho DP \& Corrêa da Costa VM 2010 Effect of serum estradiol and leptin levels on thyroid function, food intake and body weight gain in female Wistar rats. Steroids 75 638-642. (doi:10.1016/j.steroids.2010.03.009)

Pedram A, Razandi M \& Levin ER 2006 Nature of functional estrogen receptors at the plasma membrane. Molecular Endocrinology 20 1996-2009. (doi:10.1210/me.2005-0525)

Poncin S, Gérard AC, Boucquey M, Senou M, Calderon PB, Knoops B, Lengelé B, Many MC \& Colin IM 2008 Oxidative stress in the thyroid gland: from harmlessness to hazard depending on the iodine content. Endocrinology 149 424-433. (doi:10.1210/en.2007-0951)

Qiu J, Bosch MA, Tobias SC, Grandy DK, Scanlan TS, Ronnekleiv OK \& Kelly MJ 2003 Rapid signaling of estrogen in hypothalamic neurons involves a novel G-protein-coupled estrogen receptor that activates protein kinase C. Journal of Neuroscience 23 9529-9540.

Qiu J, Bosch MA, Tobias SC, Krust A, Graham SM, Murphy SJ, Korach KS, Chambon P, Scanlan TS, Rønnekleiv OK et al. 2006 A G protein-coupled estrogen receptor is involved in hypothalamic control of energy homeostasis. Journal of Neuroscience 26 5649-5655. (doi:10.1523/ JNEUROSCI.0327-06.2006)

Raad H, Eskalli Z, Corvilain B, Miot F \& De Deken X 2013 Thyroid hydrogen peroxide production is enhanced by the Th2 cytokines, IL- 4 and IL-13, through increased expression of the dual oxidase 2 and its maturation factor DUOXA2. Free Radical Biology \& Medicine 56 216-225. (doi:10.1016/j.freeradbiomed.2012.09.003)

Razandi M, Pedram A, Greene GL \& Levin ER 1999 Cell membrane and nuclear estrogen receptors (ERs) originate from a single transcript: studies of ER $\alpha$ and ER $\beta$ expressed in Chinese hamster ovary cells. Molecular Endocrinology 13 307-319. (doi:10.1210/mend.13.2. 0239)

Richardson TE, Yu AE, Wen Y, Yang SH \& Simpkins JW 2012 Estrogen prevents oxidative damage to the mitochondria in Friedreich's ataxia skin fibroblasts. PLOS ONE 7 e34600. (doi:10.1371/journal.pone. 0034600) 
Robbins J \& Nelson JH 1958 Thyroxine binding by serum protein in pregnancy and in the newborn. Journal of Clinical Investigation $\mathbf{3 7}$ 153-159. (doi:10.1172/JCI103593)

Roepke TA, Bosch MA, Rick EA, Lee B, Wagner EJ, Seidlova-Wuttke D, Wuttke W, Scanlan TS, Rønnekleiv OK \& Kelly MJ 2010 Contribution of a membrane estrogen receptor to the estrogenic regulation of body temperature and energy homeostasis. Endocrinology 151 4926-4937. (doi:10.1210/en.2010-0573)

Ruf J \& Carayon P 2006 Structural and functional aspects of thyroid peroxidase. Archives of Biochemistry and Biophysics 445 269-277. (doi:10.1016/j.abb.2005.06.023)

Salmeen A, Park BO \& Meyer T 2010 The NADPH oxidases NOX4 and DUOX2 regulate cell cycle entry via a p53-dependent pathway. Oncogene 29 4473-4484. (doi:10.1038/onc.2010.200)

Salvatore D, Davies TF, Schlumberger MJ, Hay ID \& Larsen PR 2011 Thyroid physiology and diagnostic evaluation of patients with thyroid disorders. In Williams Textbook of Endocrinology, 12th edn, pp 362-405. Eds S Melmed, KS Polonsky, PR Larsen \& HM Kronemberg. Philadelphia: W.B. Saunders Company.

Santen R, Cavalieri E, Rogan E, Russo J, Guttenplan J, Ingle J \& Yue W 2009 Estrogen mediation of breast tumor formation involves estrogen receptor-dependent, as well as independent, genotoxic effects. Annals of the New York Academy of Sciences 1155 132-140. (doi:10.1111/j.17496632.2008.03685.x)

Scandalios JG 2005 Oxidative stress: molecular perception and transduction of signals triggering antioxidant gene defenses. Brazilian Journal of Medical and Biological Research 38 995-1014. (doi:10.1590/S0100879X2005000700003)

Schaefer CJ, Geelhoed GW \& Dadu P 1986 Thyroid disorders and steroid receptor proteins. American Surgeon 52 514-518.

Schweizer U, Chiu J \& Köhrle J 2008 Peroxides and peroxide-degrading enzymes in the thyroid. Antioxidants \& Redox Signaling 10 1577-1592. (doi:10.1089/ars.2008.2054)

Seidlová-Wuttke D, Jarry H, Christoffel J, Rimoldi G \& Wuttke W 2005 Effects of bisphenol-A (BPA), dibutylphtalate (DBP), benzophenone-2 (BP2), procymidone (Proc), and linurone (Lin) on fat tissue, a variety of hormones and metabolic parameters: a 3 months comparison with effects of estradiol $\left(\mathrm{E}_{2}\right)$ in ovariectomized (ovx) rats. Toxicology $\mathbf{2 1 3}$ 13-24. (doi:10.1016/j.tox.2005.05.001)

Smanik PA, Liu Q, Furminger TL, Ryu K, Xing S, Mazzaferri EL \& Jhiang SM 1996 Cloning of the human sodium iodide symporter. Biochemical and Biophysical Research Communications 226 339-345. (doi:10.1006/bbrc. 1996.1358)

Song Y, Ruf J, Lothaire P, Dequanter D, Andry G, Willemse E, Dumont JE, Van Sande J \& De Deken X 2010 Association of duoxes with thyroid peroxidase and its regulation in thyrocytes. Journal of Clinical Endocrinology and Metabolism 95 375-382. (doi:10.1210/jc.2009-1727)

Sosić-Jurjević B, Filipović B, Milosević V, Nestorović N, ManojlovićStojanoski M, Brkić B \& Sekulić M 2005 Chronic estradiol exposure modulates thyroid structure and decreases $\mathrm{T}_{4}$ and $\mathrm{T}_{3}$ serum levels in middle-aged female rats. Hormone Research 63 48-54. (doi:10.1159/ 000083139)

Spencer NY, Yan Z, Boudreau RL, Zhang Y, Luo M, Li Q, Tian X, Shah AM, Davisson R, Davidson B et al. 2011 Control of hepatic nuclear superoxide production by glucose 6-phosphate dehydrogenase and NADPH oxidase-4. Journal of Biological Chemistry 286 8977-8987. (doi:10.1074/jbc.M110.193821)

Stanley JA, Aruldhas MM, Yuvaraju PB, Banu SK, Anbalagan J, Neelamohan R, Annapoorna K \& Jayaraman G 2010 Is gender difference in postnatal thyroid growth associated with specific expression patterns of androgen and estrogen receptors? Steroids $\mathbf{7 5}$ 1058-1066. (doi:10.1016/j.steroids.2010.06.009)

Tavangar SM, Monajemzadeh M, Larijani B \& Haghpanah V 2007 Immunohistochemical study of oestrogen receptors in 351 human thyroid glands. Singapore Medical Journal 48 744-747.

Thomasz L, Oglio R, Randi AS, Fernandez M, Dagrosa MA, Cabrini RL, Juvenal GJ \& Pisarev MA 2010 Biochemical changes during goiter induction by methylmercaptoimidazol and inhibition by deltaiodolactone in rat. Thyroid 20 1003-1013. (doi:10.1089/thy.2009.0257)

Toran-Allerand CD, Guan X, MacLusky NJ, Horvath TL, Diano S, Singh M, Connolly ES Jr, Nethrapalli IS \& Tinnikov AA 2002 ER-X: a novel, plasma membrane-associated, putative estrogen receptor that is regulated during development and after ischemic brain injury. Journal of Neuroscience 22 8391-8401.

Tunbridge WM, Evered DC, Hall R, Appleton D, Brewis M, Clark F, Evans JG, Young E, Bird T \& Smith PA 1977 The spectrum of thyroid disease in a community: the Whickham survey. Clinical Endocrinology 7 481-493. (doi:10.1111/j.1365-2265.1977.tb01340.x)

Vaiman M, Olevson Y, Habler L, Kessler A, Zehavi S \& Sandbank J 2010 Diagnostic value of estrogen receptors in thyroid lesions. Medical Science Monitor 16 BR203-BR207.

Vander JB, Gaston EA \& Dawber TR 1968 The significance of nontoxic thyroid nodules. Final report of a 15-year study of the incidence of thyroid malignancy. Annals of Internal Medicine 69 537-540. (doi:10.7326/0003-4819-69-3-537)

Vanderpump MP, Tunbridge WM, French JM, Appleton D, Bates D, Clark F, Grimley Evans J, Hasan DM, Rodgers H, Tunbridge F et al. 1995 The incidence of thyroid disorders in the community: a twenty-year follow-up of the Whickham Survey. Clinical Endocrinology 43 55-68. (doi:10.1111/j.1365-2265.1995.tb01894.x)

Vivacqua A, Bonofiglio D, Albanito L, Madeo A, Rago V, Carpino A, Musti AM, Picard D, Andò S \& Maggiolini M 2006 17ß-estradiol, genistein, and 4-hydroxytamoxifen induce the proliferation of thyroid cancer cells through the G protein-coupled receptor GPR30. Molecular Pharmacology 70 1414-1423. (doi:10.1124/mol.106.026344)

Weyemi U \& Dupuy C 2012 The emerging role of ROS-generating NADPH oxidase NOX4 in DNA-damage responses. Mutation Research 751 77-81. (doi:10.1016/j.mrrev.2012.04.002)

Weyemi U, Caillou B, Talbot M, Ameziane-El-Hassani R, Lacroix L, Lagent-Chevallier O, Al Ghuzlan A, Roos D, Bidart JM, Virion A et al. 2010 Intracellular expression of reactive oxygen species-generating NADPH oxidase NOX4 in normal and cancer thyroid tissues. EndocrineRelated Cancer 17 27-37. (doi:10.1677/ERC-09-0175)

Weyemi U, Lagente-Chevallier O, Boufraqech M, Prenois F, Courtin F, Caillou B, Talbot M, Dardalhon M, Al Ghuzlan A, Bidart JM et al. 2012 ROS-generating NADPH oxidase NOX4 is a critical mediator in oncogenic H-Ras-induced DNA damage and subsequent senescence. Oncogene 31 1117-1129. (doi:10.1038/onc.2011.327)

Yane K, Kitahori Y, Konishi N, Okaichi K, Ohnishi T, Miyahara H, Matsunaga T, Lin JC \& Hiasa Y 1994 Expression of the estrogen receptor in human thyroid neoplasms. Cancer Letters 84 59-66. (doi:10.1016/ 0304-3835(94)90358-1)

Yue W, Wang JP, Li Y, Fan P, Liu G, Zhang N, Conaway M, Wang H, Korach KS, Bocchinfuso W et al. 2010 Effects of estrogen on breast cancer development: role of estrogen receptor independent mechanisms. International Journal of Cancer 127 1748-1757. (doi:10.1002/ijc.25207)

Zeng Q, Chen GG, Vlantis AC \& van Hasselt CA 2007 Oestrogen mediates the growth of human thyroid carcinoma cells via an oestrogen receptor-ERK pathway. Cell Proliferation 40 921-935. (doi:10.1111/ j.1365-2184.2007.00471.x)

Received in final form 17 February 2014

Accepted 27 February 2014

Accepted Preprint published online 27 February 2014 http://joe.endocrinology-journals.org DOI: 10.1530/JOE-13-0588
() 2014 Society for Endocrinology Printed in Great Britain 